\title{
Effect of Manganese Exposure on the Reproductive Organs in Immature Female Rats
}

\author{
Soo In Kim ${ }^{1}$, Yeon Seok Jang ${ }^{1}$, Seung Hee Han ${ }^{1}$, Myeong Jin Choi, \\ Eun Hye Go ${ }^{1}$, Yong-Pil Cheon ${ }^{2}$, Jung Sick Lee ${ }^{3}$ and Sung-Ho Lee, \\ ${ }^{I}$ Dept. of Green Life Science, Sangmyung University, Seoul 110-743, Korea \\ ${ }^{2}$ Dept. of Biology, Sungshin Women's University, Seoul 142-732, Korea \\ ${ }^{3}$ Dept. of Aqualife Medicine, Chonnam National University, Yeosu 550-749, Korea
}

\begin{abstract}
Manganese $\left(\mathrm{Mn}^{2+}\right)$ is a trace element that is essential for normal physiology, and is predominantly obtained from food. Several lines of evidence, however, demonstrated that overexposure to $\mathrm{MnCl}_{2}$ exerts serious neurotoxicity, immunotoxicity and developmental toxicity, particularly in male. The present study aimed to evaluate the effect of $0,1.0$, 3.3 , and $10 \mathrm{mg} / \mathrm{kg} /$ day doses of $\mathrm{MnCl}_{2}$ on the reproductive organs in the immature female rats. Rats (PND 22; S.D. strain) were exposed to $\mathrm{MnCl}_{2}\left(\mathrm{MnCl}_{2} \cdot 4 \mathrm{H}_{2} \mathrm{O}\right)$ dissolved in drinking water for 2 weeks. The animals were sacrificed on PND 35, then the tissues were immediately removed and weighed. Histological studies were performed using the uteri tissue samples. Serum LH and FSH levels were measured with the specific ELISA kits. Body weights of the experimental group animals were not significantly different from those of control group animals. However, ovarian tissue weights in $1 \mathrm{mg}$ and $3.3 \mathrm{mg}$ $\mathrm{MnCl}_{2}$ dose groups were significantly lower than those of control animals ( $p<0.05$ and $p<0.01$, respectively). Uterine tissue weights of $3.3 \mathrm{mg}$ dose $\mathrm{MnCl}_{2}$ groups were significantly lower than those of control animals $(p<0.01)$, while the $1 \mathrm{mg}$ $\mathrm{MnCl}_{2}$ dose and $10 \mathrm{mg} \mathrm{MnCl}_{2}$ dose failed to induce any change in uterine weight. Similarly, only $3.3 \mathrm{mg} \mathrm{MnCl}_{2}$ dose could induce the significant decrease in the oviduct weight compared to the control group $(p<0.05)$. Non-reproductive tissues such as adrenal and kidney failed to respond to all doses of $\mathrm{MnCl}_{2}$ exposure. The uterine histology revealed that the $\mathrm{MnCl}_{2}$ exposure could affect the myometrial cell proliferation particularly in $3.3 \mathrm{mg}$ dose and 10mg dose group. Serum FSH levels were significantly decreased in $1 \mathrm{mg} \mathrm{MnCl}_{2}$ dose and $10 \mathrm{MnCl}_{2}$ mg groups ( $p<0.05$ and $p<0.01$, respectively). In contrast, treatment with $1 \mathrm{mg} \mathrm{MnCl}_{2}$ dose induced a significant increment of serum $\mathrm{LH}$ level $(p<0.05)$. The present study demonstrated that $\mathrm{MnCl}_{2}$ exposure is capable of inducing abnormal development of reproductive tissues, at least to some extent, and altered gonadotropin secretions in immature female rats. Combined with the well-defined actions of this metal on $\mathrm{GnRH}$ and prolactin secretion, one can suggest the $\mathrm{Mn}^{2+}$ might be a potential environmental mediator which is involved in the female pubertal process.
\end{abstract}

Key words : Manganese $\left(\mathrm{Mn}^{2+}\right)$, Immature female rats, Ovary, Uterus, Gonadotropins, Pubertal process

\section{INTRODUCTION}

Manganese $\left(\mathrm{Mn}^{2+}\right)$ is a trace metal and is essential element that is required for normal mammalian physiology. Several enzyme systems have been reported to interact with or depend on $\mathrm{Mn}^{2+}$ for their optimal catalytic

\footnotetext{
Corresponding author: Sung-Ho Lee, Dept. of Green Life Science, Sangmyung University, Seoul 110-743, Korea. Phone: +82-2-22875139, Fax: +82-2-2287-0098, E-mail: shlee@smu.ac.kr
}

or regulatory function (Gunter et al., 2006). On the other hand, excessive exposure to $\mathrm{Mn}^{2+}$ seems to cause serious neurotoxicity, immunotoxicity and developmental toxicity, particularly in male (Michalke et al., 2007).

Concerning the reproductive toxicity of $\mathrm{Mn}^{2+}$, studies have been focused on the mammalian testicular dysfunction. Chronic exposure to $\mathrm{Mn}_{3} \mathrm{O}_{4}$ (1,050 ppm) retarded the sexual development shown significantly smaller testis, seminal vesicle, and preputial gland weights in mice (Gray \& Laskey, 1980; Webster \& Valois, 1987). In human, 
occupational exposure to $\mathrm{Mn}^{2+}$ decreased libido and impotency (Emara et al., 1971; Mena et al., 1967), and may result in lowered sperm count and semen quality (Hjollund et al., 1998).

So far, however, research on the effect of $\mathrm{Mn}^{2+}$ exposure on female reproductive physiology has been conducted poorly. The present study aimed to evaluate the effect of $0,1.0,3.3$, and $10 \mathrm{mg} / \mathrm{kg} /$ day doses of $\mathrm{MnCl}_{2}$ on the reproductive organs in the immature female rats.

\section{MATERIALS \& METHODS}

\section{Animals}

Timely pregnant Sprague-Dawley rats were obtained from DBL (Chungcheongbuk-do, Korea) and reared in sangmyung university animal facility under conditions of 12-h light/dark cycle (lights on at 07:00 h) and constant temperature of $22 \pm 1{ }^{\circ} \mathrm{C}$. During pregnancy and lactation, the mothers had free access to normal chow and tap water. All procedures used were approved by the Animal Care and Use Committee at Sangmyung University.

\section{Experimental design}

The day after weaning (postnatal day 22, PND 22), female dams were randomly assigned to the following exposure groups ( $\mathrm{n}=8$ dams/group) from PND 22 until PND 35: (1) oral administration of $0.9 \%$ Saline (300 $\mu l$ $/ 100 \mathrm{~g} \mathrm{BW} /$ day, Control group), (2) oral administration of $1.0 \mathrm{mg} / \mathrm{kg} \mathrm{BW} /$ day $\mathrm{MnCl}_{2} \cdot 4 \mathrm{H}_{2} \mathrm{O}$ (Sigma-Aldrich), (3) oral administration of $3.3 \mathrm{mg} / \mathrm{kg} \mathrm{BW} /$ day $\mathrm{MnCl}_{2}$. $4 \mathrm{H}_{2} \mathrm{O}$, and (4) oral administration of $10 \mathrm{mg} / \mathrm{kg} \mathrm{BW} /$ day $\mathrm{MnCl}_{2} \cdot 4 \mathrm{H}_{2} \mathrm{O}$. Both saline and $\mathrm{Mn}^{2+}$ solution were supplied daily for 2 weeks. At PND 35, animals were sacrificed and the tissues(ovary, uterus, oviduct, adrenal, and kidney) were immediately removed and weighed at 1,800 hour.

\section{Histology}

Uterine tissue specimens were fixed 4\% paraformaldehyde then were serially dehydrated in graded ethanol and xylene. Specimens were paraffin embedded and sectioned at $5 \mu \mathrm{m}$ thickness. Sections were stained with HematoxylinEosin (H \& E) stain and examined under light microscope.

\section{Measurement of serum gonadotropin levels}

The trunk blood samples were collected and centrifuged at $3,000 \times \mathrm{g}$ for $15 \mathrm{~min}$. The measurements of the serum FSH and LH were carried out according to the commercial instructions for the specific ELISA kits (USCN, China). The sensitivities of the FSH and LH assay were $0.55 \mathrm{ng} / \mathrm{ml}$ and $122.5 \mathrm{pg} / \mathrm{ml}$, respectively. The intra-assay and inter-assay coefficients of variation were $<10 \%$ and $<12 \%$ for both hormones, respectively.

\section{Statistical analysis}

All values are expressed as the means ( \pm S.E.). Differences between control and treatment groups were analysed by Student's t-test. $P$ values less than 0.05 were considered significant. The IBM PC programs INSTAT and PRISM 3.0 (GraphPad, San Diego, CA, USA) were used to calculate and plot the results.

\section{RESULTS}

\section{Tissue weights}

In order to evaluate a potential effect of $\mathrm{Mn}^{2+}$ on female reproductive organs, we measured the tissues weights of ovary, uterus and oviduct. Kidney and adrenal weight served as non-reproductive tissues. After 2 weeks of administration, body weights of the all $\mathrm{Mn}^{2+}$ exposure group animals were not significantly different from those of control group animals (Fig. 1, A). However, ovarian tissue weights (Fig. 1, B). in $1 \mathrm{mg} \mathrm{MnCl}_{2}$ dose group (19.06 $\pm 0.98 \mathrm{mg}, p<0.05)$ and $3.3 \mathrm{mg} \mathrm{MnCl}_{2}$ dose group $(17.47 \pm 1.16 \mathrm{mg}, p<0.01)$ were significantly lower than those of control animals $(22.39 \pm 0.97 \mathrm{mg})$. 
Uterine tissue weights (Fig. 1, C). of $3.3 \mathrm{mg}$ dose $\mathrm{MnCl}_{2}$ groups were significantly lower than those of control animals (Control : $3.3 \mathrm{mg}$ dose $\mathrm{MnCl}_{2}=67.52 \pm 5.15$ : $50.04 \pm 2.41 \mathrm{mg}, p<0.01$ ), while the $1 \mathrm{mg} \mathrm{MnCl}_{2}$ dose (Control : $1 \mathrm{mg}$ dose $\mathrm{MnCl}_{2}=67.52 \pm 5.15: 67.11 \pm 3.28$ $\mathrm{mg}$ ) and $10 \mathrm{mg} \mathrm{MnCl}_{2}$ dose (Control : $10 \mathrm{mg}$ dose $\mathrm{MnCl}_{2}=67.52 \pm 5.15: 66.70 \pm 4.03 \mathrm{mg}$ ) failed to induce any change in uterine weight. Similarly, only $3.3 \mathrm{mg}$ $\mathrm{MnCl}_{2}$ dose could induce the significant decrease in the oviduct weight (Fig. 1, D). compared to the control group (Control : $3.3 \mathrm{mg}$ dose $\mathrm{MnCl}_{2}=7.52 \pm 0.40$ : $6.35 \pm 0.29 \mathrm{mg}, p<0.05)$. Non-reproductive tissues such as adrenal (Control : $1 \mathrm{mg}: 3.3 \mathrm{mg}: 10 \mathrm{mg}$ dose $\mathrm{MnCl}_{2}$
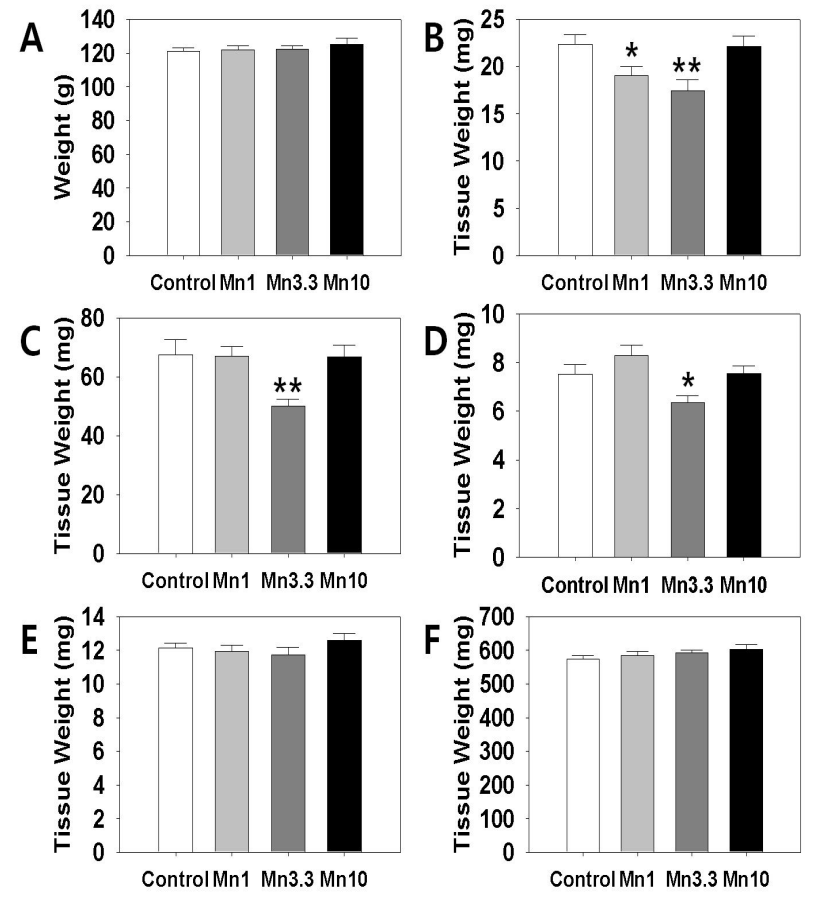

Fig. 1. Effect of $\mathrm{MnCl}_{2}$ exposure on changes in body weights and tissues weights. Animals were daily supplied $0.9 \%$

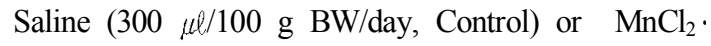
$4 \mathrm{H}_{2} \mathrm{O}(1.0 \mathrm{mg} / \mathrm{kg} \mathrm{BW}, 3.3 \mathrm{mg} / \mathrm{kg} \mathrm{BW}, 10 \mathrm{mg} / \mathrm{kg} \mathrm{BW}$, respectively) for 2 weeks. $\mathrm{A}$, body weight; $\mathrm{B}$, ovary; $\mathrm{C}$, uterus, D, oviduct, E, adrenal, and F, kidney. Values are expressed as mean \pm S.E. ( $\mathrm{n}=8$ per group). ${ }^{*}$, Significantly different from control group, $p<0.05$. **, Significantly different from control group, $p<0.01$.
$=12.13 \pm 0.28: 11.93 \pm 0.38: 11.75 \pm 0.42: 12.59 \pm 0.43$ $\mathrm{mg}$ ) and kidney (Control : $1 \mathrm{mg}: 3.3 \mathrm{mg}: 10 \mathrm{mg}$ dose $\mathrm{MnCl}_{2}=574.74 \pm 8.99: 584.56 \pm 12.38: 592.42 \pm 7.82:$ $603.67 \pm 14.06 \mathrm{mg}$ ) failed to respond to all doses of $\mathrm{MnCl}_{2}$ exposure (Fig. 1, E \& F, respectively).

\section{Uterine histology}

To access the histological changes in $\mathrm{MnCl}_{2}$ exposured uteri, standard paraffin section and hematoxylin-eosin staining method were employed. $3.3 \mathrm{mg}$ and $10 \mathrm{mg}$ $\mathrm{MnCl}_{2}$ dose groups shown the thickend myometrial layer when compared to control (Fig. 2, Mn3.3 \& Mn10). In contrast, $1 \mathrm{mg} \mathrm{MnCl}_{2}$ exposure reduced the thickness of myometrium (Fig. 2, Mn1).

\section{ELISA}

Serum LH and FSH levels were measured using specific ELISA kits. Fig. 3 (A) shows that the secretion of FSH was significantly decreased by treatment with $1 \mathrm{mg}$ or $3.3 \mathrm{mg} \mathrm{MnCl}{ }_{2}$ (Control: $1 \mathrm{mg}$ dose $\mathrm{MnCl}_{2}=3.54 \pm 0.18$ : $3.07 \pm 0.14 \mathrm{ng} / \mathrm{ml}, p<0.05$; Control : $10 \mathrm{mg}$ dose $\mathrm{MnCl}_{2}$ $=3.54 \pm 0.18: 2.75 \pm 0.10 \mathrm{ng} / \mathrm{ml}, p<0.01)$. Serum LH level was significantly elevated by $1 \mathrm{mg} \mathrm{MnCl}_{2}$ exposure (Control : $1 \mathrm{mg}$ dose $\mathrm{MnCl}_{2}=39.85 \pm 8.93: 76.71 \pm 12.36$ $\mathrm{ng} / \mathrm{ml}, p<0.05$, Fig. 3, B). Higher doses of $\mathrm{MnCl}_{2}$ exposure failed to change the serum $\mathrm{LH}$ levels.

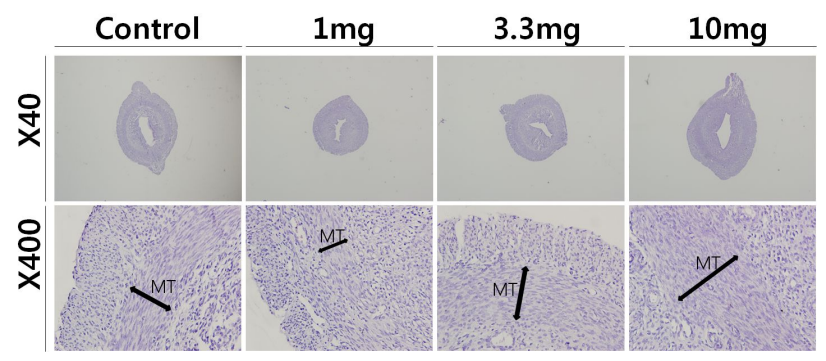

Fig. 2. Effect of $\mathrm{MnCl}_{2}$ exposure on histological changes in uteri from immature rats. Standard paraffin section and hematoxylin-eosin staining method were employed. Mn $1,1.0 \mathrm{mg} / \mathrm{kg} \mathrm{BW} /$ day of $\mathrm{MnCl}_{2} \cdot 4 \mathrm{H}_{2} \mathrm{O}$ exposure; $\mathrm{Mn} 3.3$, $3.3 \mathrm{mg} / \mathrm{kg} \mathrm{BW} /$ day of $\mathrm{MnCl}_{2} \cdot 4 \mathrm{H}_{2} \mathrm{O}$ exposure; $\mathrm{Mn} 10$, $10 \mathrm{mg} / \mathrm{kg} \mathrm{BW} /$ day of $\mathrm{MnCl}_{2} \cdot 4 \mathrm{H}_{2} \mathrm{O}$ exposure, respectively. 

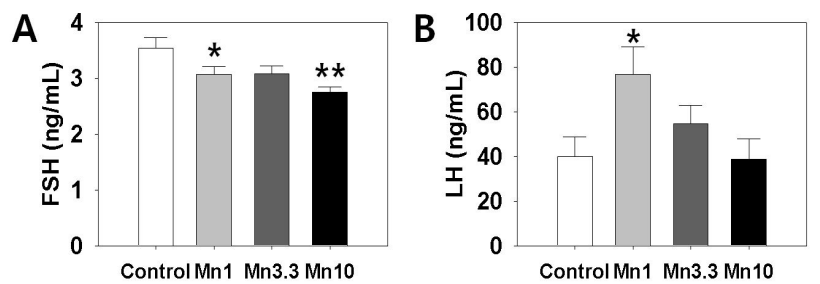

Fig. 3. Measurement of serum FSH and LH levels in response to $\mathrm{Mn}^{2+}$ exposure. The trunk blood samples were collected and centrifuged at $3,000 \times \mathrm{g}$ for $15 \mathrm{~min}$. The measurements of the serum FSH and $\mathrm{LH}$ were carried out according to the commercial instructions for the specific ELISA kits (USCN, China). Values are expressed as mean \pm S.E. ( $n=6$ per group). *, Significantly different from control group, $p<0.05$. **, Significantly different from control group, $p<0.01$.

\section{DISCUSSION}

In the present study we demonstrated that the $\mathrm{Mn}^{2+}$ exposure could change the weights of reproductive tissues in immature female rats. Although we failed to find the advance or delay of puberty onset in the $\mathrm{Mn}^{2+}$ exposured animals (data not shown), the potential reproductive toxicity of this metal in immature female rats cannot be ruled out. $\mathrm{Mn}^{2+}$ exposure, Indeed, not only affected the proliferative activity in myometrial layer, but induced significant changes in the serum FSH and LH levels.

More defined doses and exposure periods will be helpful to verify the physiological relevance of $\mathrm{Mn}^{2+}$ exposure in female reproduction.

Occupational exposure to $\mathrm{Mn}^{2+}$ could be occurred often at the workplaces such are mines and dried battery factories (Emara et al., 1971; Mena et al., 1967). In this respect, most studies on the toxicological effects of $\mathrm{Mn}^{2+}$ have been focused on the men. Furthermore, a relatively small portion of the studies dealt with reproductive toxicity of $\mathrm{Mn}^{2+}$ exposure using male animal models. $\mathrm{Mn}^{2+}$ exposure for 2 and $4 \mathrm{~h}$ inhibited rat primary Leydig cell steroidogenesis by decreasing StAR protein expression while 24 and $48 \mathrm{~h}$ exposure of $\mathrm{MnCl}_{2}$ caused adverse effects on both StAR protein and P450scc and 3b-HSD enzyme activity to reduce steroidogenesis (Cheng et al., 2003).

Pine et al. (2005) reported that $\mathrm{Mn}^{2+}$ administered acutely into the third ventricle shown dose-dependently to stimulate LH release in prepubertal female rat, and this effect was due to a $\mathrm{Mn}^{2+}$-induced stimulation of GnRH. The authors demonstrated that $\mathrm{Mn}^{2+}$ can stimulate specific puberty-related hormones and suggested that it may facilitate the normal onset of puberty. According to them, $\mathrm{Mn}^{2+}$ may contribute to precocious puberty if an individual is exposed to elevated levels of $\mathrm{Mn}^{2+}$ too early in developmental process. This hypothesis was verified by same research group; Lee et al. (2006) demonstrated that $\mathrm{Mn}^{2+}$ is a direct stimulator of prepubertal GnRH/LH secretion and may facilitate the normal onset of male puberty. Their data that $\mathrm{Mn}^{2+}$ can cause GnRH release in adult males, suggested this action should be considered in relation to age, gender, as well as mechanistic and functional differences between adult and immature animals.

In the present study we failed to confirm the advanced puberty onset in $\mathrm{Mn}^{2+}$ exposed female rats (up to 10 $\mathrm{mg} / \mathrm{kg}$ BW, data not shown). Pine et al. (2005) shown that same dose of $\mathrm{Mn}^{2+}$ exposure initiated a moderate but significant advancement in age at vaginal opening (VO) in terms of days (1.5 days). The only difference between the two studies was timing and duration of $\mathrm{Mn}^{2+}$ exposure; Our treatment regimen was PND 21-35 (14 days), and theirs was PND 12-29 (18 days). Though $\mathrm{Mn}^{2+}$ can acutely induce GnRH secretion in adult males, one should consider that additional action of $\mathrm{Mn}^{2+}$ to release GABA, a GnRH inhibitor, may ultimately contribute to suppressed reproductive function observed in adult animals following exposure to high chromic levels of $\mathrm{Mn}^{2+}$ (Prestifilippo et al., 2008). Because neurotransmitter secretory circuits in female during peripubertal period are remarkably unstable, the extent of GABA- 
GnRH regulation, and probably more neuronal regulation, may vary responding to the minor difference. Studies indicate the more specific action mechanism of $\mathrm{Mn}^{2+}$ within the hypothalamus; $\mathrm{Mn}^{2+}$ activates soluble guanylate cyclase (sGC) directly and/or as a cofactor with available nitric oxide (NO), hence generating cGMP and resulting in prepubertal GnRH release (Lee et al., 2007). More recently, $\mathrm{Mn}^{2+}$, through the upregulation of IGF-1 and COX-2, may promote maturational events and glialneuronal communications facilitating the increased neurosecretory activity, including that of $\mathrm{GnRH}$, resulting in precocious pubertal development (Hiney et al., 2011).

Special emphasis should be made on the action of $\mathrm{Mn}^{2+}$ in brain. Inhalation of the mixture of $\mathrm{MnCl}_{2}$ and $\mathrm{Mn}(\mathrm{OAc})_{3}$ for 5 months developed movement abnormalities, significant loss of substantia nigra compacta (SNc) dopaminergic neurons; these symptoms similar to those observed in Parkinson disease (PD) (Ordoñez-Librado et al., 2010). Dopamine (DA) depletion is closely related to pituitary prolactin biosynthesis. Male rats exposed to $\mathrm{Mn}^{2+}$ for 4 or 13 weeks showed a progressive and significant decrease in hypothalamic DA, whereas prolactin and Pit-1 mRNA levels increased in response to $\mathrm{Mn}^{2+}$ exposure (Kim et al., 2009). These results suggest that exposure to $\mathrm{Mn}^{2+}$ decreases hypothalamic DA and promotes the production of prolactin in the pituitary and that Pit-1 might be a regulator of DA and prolactin. Furthermore, such $\mathrm{Mn}^{2+}$ exposure induced significant increase in serum prolactin levels seemed to be highly correlated with the testis toxicity (Lee, 2009). In this context, relationship between $\mathrm{Mn}^{2+}$ exposure and DA/ prolactin secretions in immature female rats will be helpful to understand the function of the metal during pubertal development.

\section{REFERENCES}

Cheng J, Fu J-L, Zhou Z-C (2003) The inhibitory effects of manganese on steroidogenesis in rat primary Leydig cells by disrupting steroidogenic acute regulatory (StAR) protein expression. Toxicology 187:139-148. Emara AM, el-Ghawabi SH, Madkour OI, el-Samra GH (1971) Chronic manganese poisoning in the dry battery industry. Br J Ind Med 28:78-82.

Gray LE Jr, Laskey JW (1980) Multivariate analysis of the effects of manganese on the reproductive physiology and behavior of the male house mouse. $\mathrm{J}$ Toxicol Environ Health 6:861-867.

Gunter TE, Gavin CE, Aschner M, Gunter KK (2006) Speciation of manganese in cells and mitochondria: a search for the proximal cause of manganese neurotoxicity. Neurotoxicology 27:765-776.

Hiney JK, Srivastava VK, Dees WL (2011) Manganese induces IGF-1 and cyclooxygenase-2 gene expressions in the basal hypothalamus during prepubertal female development. Toxicol Sci 121:389-396.

Hjollund NH, Bonde JP, Jensen TK, Ernst E, Henriksen TB, Kolstad HA, Giwercman A, Skakkebaek NE, Olsen J (1998) Semen quality and sex hormones with reference to metal welding. Reprod Toxicol 12:91-95.

Kim HY, Lee CK, Lee JT, Moon CS, Ha SC, Kang SG, Kim DH, Kim HD, Ahn JH, Lee SB, Kang MG (2009) Effects of manganese exposure on dopamine and prolactin production in rat. Neuroreport 20:69-73.

Lee B, Pine M, Johnson L, Rettori V, Hiney JK, Dees WL (2006) Manganese acts centrally to activate reproductive hormone secretion and pubertal development in male rats. Reprod Toxicol 22:580-585.

Lee B, Hiney JK, Pine MD, Srivastava VK, Dees WL (2007) Manganese stimulates luteinizing hormone releasing hormone secretion in prepubertal female rats: hypothalamic site and mechanism of action. $\mathrm{J}$ Physiol 578(Pt 3):765-772.

Lee CK (2009) Effects of manganese exposure on the testis function and serum prolactin concentration in rat. Devel Reprod 13:321-327. 
Mena I, Marin O, Fuenzalida S, Cotzias GC (1967) Chronic manganese poisoning. Clinical picture and manganese turnover. Neurology 17:128-136.

Michalke B, Halbach S, Nischwitz V (2007) Speciation and toxicological relevance of manganese in humans. J Environ Monit 9:650-656.

Ordoñez-Librado JL, Anaya-Martínez V, Gutierrez-Valdez AL, Colín-Barenque L, Montiel-Flores E, Avila-Costa MR (2011) Manganese inhalation as a Parkinson disease model. Parkinsons Dis doi:10.4061/2011/ 612989

Pine M, Lee B, Dearth R, Hiney JK, Dees WL (2005) Manganese acts centrally to stimulate luteinizing hormone secretion: a potential influence on female pubertal development. Toxicol Sci 85:880-885.

Prestifilippo JP, Fernández-Solari J, Mohn C, De Laurentiis
A, McCann SM, Dees WL, Rettori V (2007) Effect of manganese on luteinizing hormone-releasing hormone secretion in adult male rats. Toxicol Sci 97:75-80. Prestifilippo JP, Fernández-Solari J, De Laurentiis A, Mohn CE, de la Cal C, Reynoso R, Dees WL, Rettori V (2008) Acute effect of manganese on hypothalamic luteinizing hormone releasing hormone secretion in adult male rats: involvement of specific neurotransmitter systems. Toxicol Sci 105:295-302.

Webster WS, Valois AA (1987) Reproductive toxicology of manganese in rodents, including exposure during the postnatal period. Neurotoxicology 8:437-444.

(Received 13 November 2012, Received in revised form 3 December 2012, Accepted 8 December 2012) 